\title{
Peptides Containing the RERMS Sequence of Amyloid $\beta /$ A4 Protein Precursor Bind Cell Surface and Promote Neurite Extension
}

\author{
Lee-Way Jin, ${ }^{1}$ Haruaki Ninomiya, ${ }^{1}$ Jean-Marc Roch, ${ }^{1}$ David Schubert, ${ }^{2}$ Eliezer Masliah, ${ }^{1}$ Deborah A. C. Otero, ${ }^{1}$ \\ and Tsunao Saitoh'
}

'Department of Neurosciences, School of Medicine, University of California, San Diego, La Jolla, California 92093-0624 and ${ }^{2}$ The Salk Institute for Biological Studies, San Diego, California 92128

Amyloid $\beta /$ A4 protein precursor (APP) is secreted into medium by most cultured cells and can function as an autocrine factor. To study the biological function of secreted forms of APP (sAPP) on neurons, we used a clonal CNS neuronal line, B 103, which does not synthesize detectable levels of APP. B103 cells transfected with APP construct developed neurites faster than the parent $B 103$ cells when plated in a serum-free defined medium. Neurite outgrowth of B103 cells was promoted by the conditioned medium of APP-695-overproducing cells or by the bacteria-produced SAPP-695 (named KB75). A series of peptides having sequences between Ala-319 and Met-335 of APP-695 also stimulated neurite outgrowth of $B 103$ cells. The sequence of five amino acids, RERMS (APP 328-332), within this stretch of sequence, was the shortest active peptide, although the concentration required for the neuritotropic activity was higher than that of KB75. Binding assay using ${ }^{125}$-labeled APP 17mer peptide corresponding to Ala-319 to Met-335 of APP. 695 as a ligand demonstrated specific and saturable cellsurface binding sites. The predicted $K_{D}$ value was $20 \pm 5 \mathrm{~nm}$ and the $B_{\max }$ value was $80 \pm 8 \mathrm{fmol} / 10^{6}$ cells. The binding could be displaced with KB75. A 17-mer peptide with reverse sequence neither induced neurite outgrowth nor competed for the binding. A bacteria-produced SAPP fragment lacking the active 17-mer sequence (named KB758) did not compete with ${ }^{125}$-labeled 17-mer for binding or stimulate neurite extension. A peptide of sequence RMSQ (APP 330-333), which partially overlaps the active sequence RERMS, could block the neuritotropic effects of both KB75 and the 17-mer at higher concentrations. APP 17-mer was also found to induce the accumulation of inositol polyphosphates, suggesting that the APP 17-mer effects involve activation of inositol phospholipid signal transduction systems. These data indicate that SAPP induces neurite extension through cell-surface binding and that the domain containing the RERMS sequence (APP 328-332) represents the active site responsible for this function.

\footnotetext{
Received Oct. 4, 1993; revised Feb. 25, 1994; accepted Mar. 15, 1994.

L.-W.J. and H.N. made equal contributions to the present study. This research was supported by National Institutes of Health Grant AG05131. H.N. was supported by the Fogarty International Fellowship (TW04602) from the Department of Health and Human Services, Public Health Services, National Institutes of Health. J.-M.R. was supported by a grant from the Swiss National Science Foundation (623A-028366). We thank Robert Davignon and Isabelle Hafner for editorial help in the preparation of the manuscript, and Bey-Ley Chen and Richard DeTeresa for assistance in the quantification of neurite length.

Correspondence should be addressed to Tsunao Saitoh at the above address. Copyright (C) 1994 Society for Neuroscience $0270-6474 / 94 / 145461-10 \$ 05.00 / 0$
}

IKey words: Alzheimer's disease, amyloid $\beta / A 4$ precursor protein, growth factor, trophic factor, receptor, signal transduction]

Amyloid $\beta / \mathrm{A} 4$ protein (A $\beta$ ), a major component of both the plaque and vascular amyloid in the brain tissue of patients afflicted with Alzheimer's disease (AD) (Glenner and Wong, 1984; Masters et al., 1985; Selkoe et al., 1986), is a peptide of about $4.2 \mathrm{kDa}$ produced by cleavage of a large precursor molecule, amyloid $\beta /$ A4 protein precursor (APP) (Goldgaber et al., 1987; Kang et al., 1987; Robakis et al., 1987; Tanzi et al., 1987). There are three major isoforms of APP resulting from differential splicing of a primary RNA transcript. APP-695 shares the same amino acid sequence with APP-751 and APP-770 except that it does not contain a domain showing a strong homology with Kunitz-type protease inhibitors (KPI) (Kitaguchi et al., 1988; Ponte et al., 1988; Tanzi et al., 1988). APPs with and without the KPI domain are secreted into the growth-conditioned medium (CM) of cultured cells (Schubert et al., 1988, 1989; Refolo et al., 1989; Weidemann et al., 1989). The secretory pathway involves a proteolytic cleavage either at $\beta 16$ within $\mathrm{A} \beta$ (Esch et al., 1990; Sisodia et al., 1990; Anderson et al., 1991; Wang et al., 1991) or at the amino terminus of $\mathrm{A} \beta$ (Seubert et al., 1993), releasing the long $\mathrm{N}$-terminal fragment (secreted APP, sAPP) into the medium. sAPPs are also found in plasma and cerebrospinal fluid (Selkoe et al., 1988; Ghiso et al., 1989; Palmert et al., 1989a,b; Podlisny et al., 1990; Prior et al., 1991; Van Nostrand et al., 1992), suggesting a biological significance in vivo. Consistent with this idea, purified sAPPs were shown to have trophic activities on cultured fibroblasts (Saitoh et al., 1989; Bhasin et al., 1991), cortical neuronal cells (Araki et al., 1991), and PC12 cells (Milward et al., 1992), and to protect culture neurons from hypoglycemia-induced cytotoxicity (Mattson et al., 1993). N-terminal epitopes of APP were also found in the neurites of neuritic plaques (Arai et al., 1990; Cole et al., 1991; Cras et al., 1991; Joachim et al., 1991; Shoji et al., 1991; Cummings et al., 1992; Masliah et al., 1992a,b) and growing axons (Masliah et al., 1992c), suggesting that APP may play a role in neuritic sprouting in the brain. On the other hand, membranebound APP has a receptor-like architecture (Kang et al., 1987), with a region in the cytoplasmic domain capable of complexing with GTP-binding protein (Nishimoto et al., 1993). We have previously identified a small stretch of the sAPP sequence as the active site in the regulation of fibroblast growth (Roch et al., 1992; Ninomiya et al., 1993). In the present study, we asked whether this sequence of APP was also active on neuronal cells in terms of neurite extension. 


\section{A}
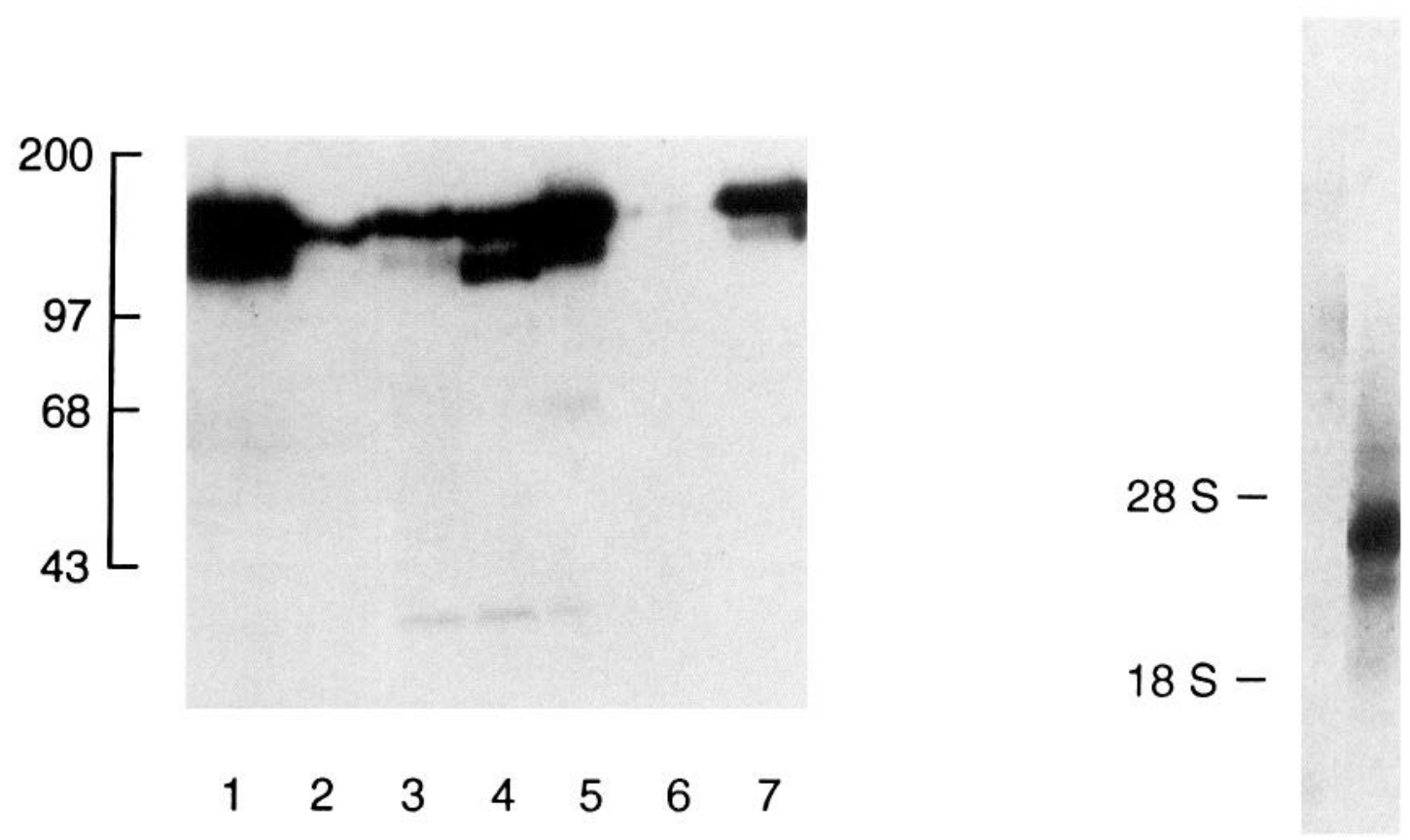

12

Figure 1. B103 neuron-like cells do not express APP. A, Several clones of neuronal cell lines were compared for the amount of APP secreted; 3.5 $\times 10^{5}$ cells were plated onto $100 \mathrm{~mm}$ tissue culture dishes in $3.5 \mathrm{ml}$ of serum-free medium and cultured for $18 \mathrm{hr}$. Medium was then harvested and spun at $\sim 500 \times g$ for $5 \mathrm{~min}$, and supernatant was passed through a $0.45 \mu \mathrm{m}$ pore filter and desalted using a Sephadex G50 column. Ten micrograms of medium protein were electrophoresed on $7.5 \%$ polyacrylamide gels containing SDS, transferred to nitrocellulose, and immunostained with anti-GID, an antibody against APP residues 175-186 (Saitoh et al., 1989). The cells from which the CM was analyzed were as follows: lane 1, PC12; lane 2, R33, a line from rat retina; lane 3, B35; lane 4, B50; lane 5, B65; lane 6, B103; and lane 7, B104. B35, B50, B65, B103, and B104 are clones of nerve cells derived from rat brain (Schubert et al., 1974). The scale shows the molecular weight in kilodaltons. B, Total RNA was extracted from exponentially growing cells by the acid phenol method (Chomczynski and Sacchi, 1987). Ten micrograms of total RNA were separated on a $1 \%$ agarose gel, transferred onto a nylon membrane, and hybridized with the ${ }^{32} \mathrm{P}-$ labeled $1.1 \mathrm{~kb}$ EcoR 1 fragment of human APP cDNA. Lane 1, RNA from B103; lane 2, RNA from PC12. The locations of $28 \mathrm{~S}$ and $18 \mathrm{~S}$ ribosomal RNA are indicated.

\section{Materials and Methods}

The APP peptides. APP peptides used in this study were synthesized using a Rainin PS3 peptide synthesizer and purified on a C-18 reversephase HPLC column. The peptides were purified in a gradient of acetonitrile. This solvent was eliminated by evaporation under vacuum, and the peptides were resolubilized in $50 \mathrm{~mm} \mathrm{NaHCO}_{3}(\mathrm{pH} 7.4)$. Since $\mathrm{C} 6$ and $\mathrm{C} 7$ peptides were not soluble in this buffer, they were initially solubilized in a small amount of dimethyl sulfoxide (DMSO) and then diluted to give a final concentration of DMSO in the culture medium of less than $0.1 \%$.

Preparation of APP-overproducing cells. The experimental conditions are reported elsewhere (Schubert and Behl, 1993). Briefly, a fragment of human APP-695 cDNA including full coding sequence was subcloned into pORFex 13 (Bernard et al., 1987), in which the expression of APP695 was driven by cytomegalovirus promoter. Clonal B103 cells were then cotransfected with pSV-2neo and the APP expression plasmid using a standard calcium phosphate method. Stably transfected lines were selected with $400 \mu \mathrm{g} / \mathrm{ml} \mathrm{G} 418$ and cloned.

The neurite extension assay. B103 cell clones were maintained in DMEM supplemented with $10 \%$ FBS. For the experiments in serumfree condition, late exponentially dividing $\mathrm{B} 103$ cells were washed twice with PBS, dissociated by gentle trituration in PBS, spun down, brought up in N2 medium (Bottenstein and Sato, 1979), and plated at a density of $5 \times 10^{3} / \mathrm{cm}^{2}$.

Because fixation of cells may change their morphology, for the purpose of accurate quantification cells were photographed under phase optics 20 or $30 \mathrm{hr}$ after plating. Each experimental condition was either in triplicate (in a 24 well plate) or sextuplicate (in a 96 well plate) and was repeated at least twice. Routinely we photographed the central portion of each well with the best phase contrast, excluding the small number of fields containing unusual cell density or cell aggregates. Neurite numbers and lengths were quantified with the aid of a morphometric program on a Quantimet. A neurite was defined as a cellular process longer than the longest diameter of the cell body. The sum of either neurite numbers or neurite lengths was then divided by the number of cells counted. At least 200 cells were counted in each experimental condition.

The APP binding assay. The 17-mer peptide was iodinated with ${ }^{125} \mathrm{I}-$ Bolton-Hunter reagent (Amersham Co.; $2000 \mathrm{Ci} / \mathrm{mmol}, 500 \mu \mathrm{Ci}$ ) according to the manufacturer's instructions. In brief, the peptide solution (10 $\mu \mathrm{g}$ in $10 \mu \mathrm{l}$ of $0.1 \mathrm{~m} \mathrm{NaHCO}$ buffer, $\mathrm{pH} \mathrm{8.5)}$ was incubated with the dried reagent at $4^{\circ} \mathrm{C}$ overnight. The reaction was quenched with glycine $\left(100 \mu \mathrm{l}\right.$ of $1 \mathrm{mg} / \mathrm{ml}$ solution in $\left.\mathrm{H}_{2} \mathrm{O}\right)$ and the iodinated peptide was separated from the unincorporated reagent through Sephadex G15 column $\left(1 \mathrm{~cm}^{2} \times 25 \mathrm{~cm}\right)$ saturated with PBS containing $0.15 \%$ gelatin (PBSG). The specific activity of the ${ }^{125}$ I-17-mer thus obtained was 40 

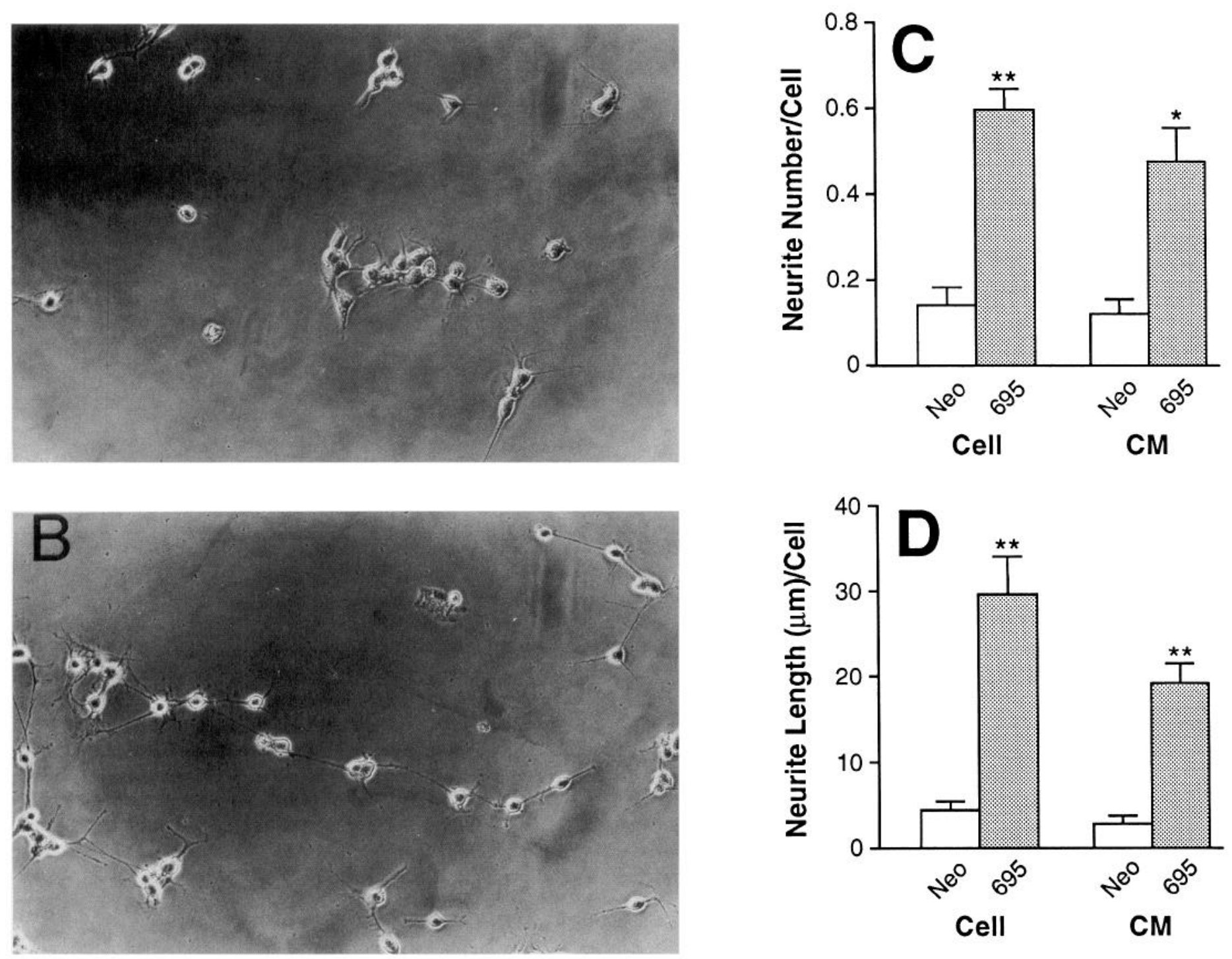

Figure 2. B103 cells overexpressing APP-695 grow more and longer neurites than vector-transfected control cells. Thirty hours after plating, photomicrographs from $\mathrm{B} 103 / \mathrm{Neo} / \mathrm{Cl} 3(A)$ and $\mathrm{B} 103 / 695 / \mathrm{Cl} 7(B)$ were taken. The comparison of neurite numbers per cell between $\mathrm{B} 103 / \mathrm{Neo} / \mathrm{Cl} 3$ and B103/695/Cl7 at $20 \mathrm{hr}$ after plating is presented in $C$, and that of neurite length per cell, in $D$. Data presented are means \pm SEM of a typical experiment. The replicate experiments gave essentially the same result. For the $\mathrm{CM}$ experiments, serum-free $\mathrm{CM}$ from $10 \mathrm{hr}$ cultures of each cell line $\left(5 \times 10^{3} / \mathrm{cm}^{2}\right)$ was transferred to a new plate of $\mathrm{B} 103$ culture so that the final concentration of CM was $50 \%$. The absence and presence of APP in the CM of B103/neo/ $\mathrm{Cl} 3$ and B103/695/Cl7, respectively, were confirmed by immunoblotting using several anti-APP antibodies. In a 20 $\mathrm{hr}$ period, B103/695/Cl7 grew more and longer neurites per cell compared to $\mathrm{B} 103 / \mathrm{neo} / \mathrm{Cl} 3$, and $\mathrm{CM}$ from $\mathrm{B} 103 / 695 / \mathrm{Cl} 7$ induced more and longer neurites from B103 compared to that from B103/neo/Cl3. Error bars indicate SEM throughout. Asterisks indicate significant differences relative to the effect of neo vector transfection control revealed by Student's $t$ test $\left({ }^{*}, p<0.05 ;{ }^{* *}, p<0.01\right)$. In testing the neurite extension effect of sAPP, we found no qualitative difference between neurite length measurement and neurite number measurement as an index of neurite extension. Therefore, only the neurite number measurement is demonstrated in the later experiments.

$60 \mathrm{Ci} / \mathrm{mmol}$. For the binding assays, B103 cells in the late log phase were harvested in PBS, spun down at $1200 \times \mathrm{g}$ for $5 \mathrm{~min}$, and resuspended in Dulbecco's modified Eagle's medium (DMEM) $/ 5 \%$ fetal bovine serum (FBS). The suspension $\left(4 \times 10^{5}\right.$ cells $\left./ \mathrm{ml}\right)$ was seeded in a 24-well plate $\left(0.5 \mathrm{ml} /\right.$ well) and the plate was kept at $37^{\circ} \mathrm{C}$ in a $\mathrm{CO}_{2}$ incubator for $3 \mathrm{hr}$. The plate was then transferred on ice and the medium was immediately replaced with ice-cold PBSG. After $30 \mathrm{~min}$, the binding reaction was started by replacing the PBSG with fresh, ice-cold PBSG containing ${ }^{125} \mathrm{I}-17$-mer peptide and various competitor peptides as indicated. The reaction volume was $0.25 \mathrm{ml}$. After various lengths of time, the binding media were aspirated and the cell layer was washed three times with $0.5 \mathrm{ml}$ of ice-cold PBSG. The radioactivity remaining on the cell layer was then recovered in $0.5 \mathrm{ml}$ of the extraction buffer $(0.5 \%$ Triton X-100, $0.1 \mathrm{~m} \mathrm{NaHCO}, \mathrm{pH} 7.4)$ and counted in a gamma counter. All the binding assays were done in triplicate.
Inositol polyphosphates assay. B103 cells in the late log phase were harvested in PBS and resuspended in complete growth medium with the density of $1 \times 10^{5} \mathrm{cells} / \mathrm{ml}$. ${ }^{3} \mathrm{H}$-inositol (Amersham, Arlington Heights, IL) was then added to the cell suspension at $5-10 \mu \mathrm{Ci} / \mathrm{ml}$ and $0.25 \mathrm{ml}$ of the suspension was plated into each well in a 24-well plate. After incubation for $24 \mathrm{hr}$, the cells were washed once with KrebsHensleit buffer with $\mathrm{LiCl}$ (KHL buffer, composed of $100 \mathrm{~mm} \mathrm{NaCl}, 4.7$ $\mathrm{mm} \mathrm{KCl}, 1.3 \mathrm{~mm} \mathrm{CaCl}, 1.2 \mathrm{mM} \mathrm{KH}_{2} \mathrm{PO}_{4}, 1.2 \mathrm{~mm} \mathrm{MgSO}_{4}, 25 \mathrm{~mm}$ $\mathrm{NaHCO}_{3}, 11.7 \mathrm{~mm}$ glucose, and $20 \mathrm{~mm} \mathrm{LiCl}$ ) previously equilibrated with $5 \% \mathrm{CO}_{2}$. APP peptides in $300 \mu \mathrm{l}$ of KHL buffer were then added to each well and the cultures were incubated in the $\mathrm{CO}_{2}$ incubator for $30 \mathrm{~min}$. The incubations were terminated by adding $100 \mu \mathrm{l} /$ well icecold $10 \%$ perchloric acid, neutralized with $\mathrm{KOH}$, and the cellular debris was pelleted by centrifugation. The supernatants were applied to small columns containing Dowex anion-exchange resin AG1 x8 (100-200 mesh, 


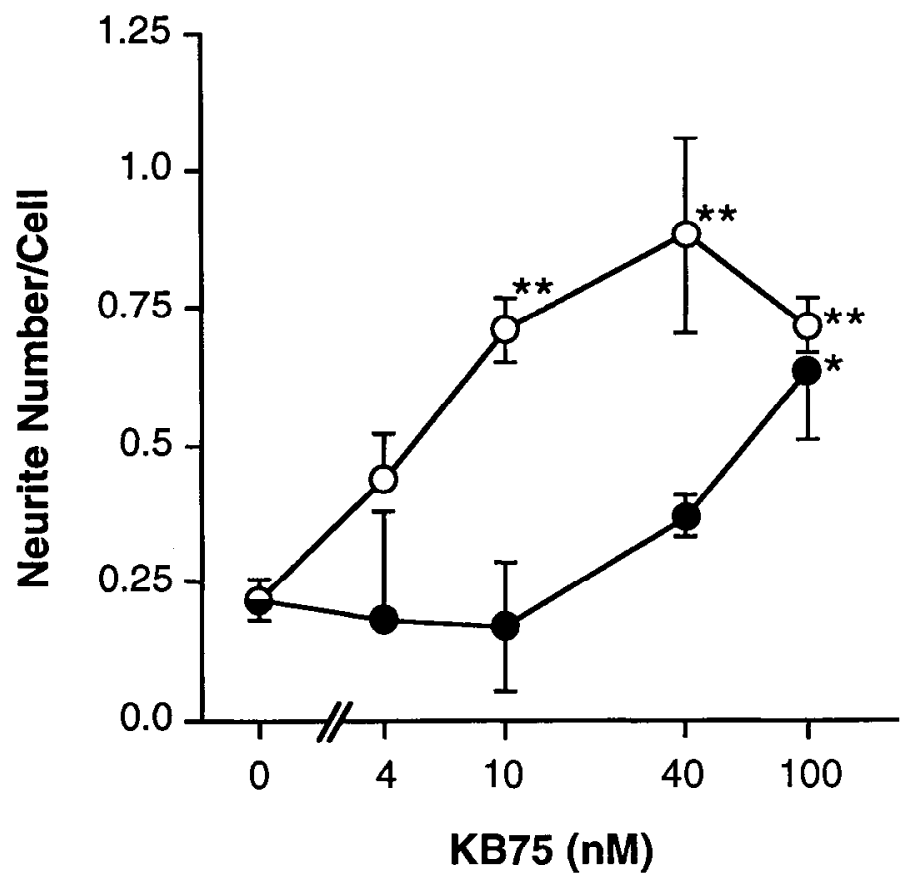

Figure 3. KB75 increases neurite numbers per cell. B103 cells were cultured in the presence (O) or absence (O) of $200 \mu \mathrm{M}$ RMSQ peptide with the indicated concentration of $\mathrm{KB} 75$ for $20 \mathrm{hr}$. The presence of RMSQ resulted in a shift of the dose-response curve of $\mathrm{KB} 75\left(^{*}, p<\right.$ $0.05 ; * *, p<0.01$; compared with no treatment). Note that $100 \mathrm{~nm}$ KB75 treatment overcame the inhibitory effect of $200 \mu \mathrm{M}$ RMSQ.

Bio-Rad, Hercules, CA) to separate total inositol phosphates from inositol. The columns were washed with water and ${ }^{3} \mathrm{H}$-inositol phosphates were eluted with $2 \mathrm{ml}$ of $1 \mathrm{~N} \mathrm{HCl}$ directly into scintillation vials containing $10 \mathrm{ml}$ of scintillation cocktail (Ecolume, ICN Biomedicals, Irvine, $\mathrm{CA}$ ).

Adhesion assay. Exponentially dividing B 103 cells were metabolically labeled with ${ }^{3} \mathrm{H}$-leucine $(5 \mu \mathrm{Ci} / \mathrm{ml})$ for $15 \mathrm{hr}$. The cells were collected without using any trypsin or chelating agents, washed three times with HEPES-buffered DME containing 0.4\% BSA, and resuspended in the same solution. Aliquots of $2 \mathrm{ml}$ containing $1 \times 10^{5}$ cells were pipetted into $35 \mathrm{~mm}$ petri dishes pretreated with and without the peptides. After incubation at $37^{\circ} \mathrm{C}$ for $30 \mathrm{~min}$, the dishes were swirled 10 times, the medium was aspirated, the remaining attached cells were dissolved in $3 \%$ Triton X-100, and their isotope content was determined. To adsorb peptides to the dish surface, dishes covered by $0.5 \mathrm{ml}$ of DME containing the peptides were incubated overnight at $37^{\circ} \mathrm{C}$, and then washed twice with DME and once with HEPES-buffered DME containing $0.4 \%$ BSA.

\section{Results}

B103 rat CNS neuronal cells do not synthesize or secrete APP All cell lines with neuronal characteristics that we have screened so far secrete abundant APP into the media (Fig. 1) except for the cell line B103 (Schubert et al., 1974). Because sAPP's action is probably through an autocrine mechanism in cell culture (Saitoh et al., 1989; Araki et al., 1991; Bhasin et al., 1991; Milward et al., 1992), it would be difficult to demonstrate the effect of exogenously applied APP to cells actively secreting APP. Either the effect of applied APP would be masked or the APP-mediated mechanism would be downregulated or saturated by endogenous APP. Therefore, we employed B 103 cells for our experiments. In contrast to fibroblasts (Saitoh et al., 1989; Bhasin et al., 1991), APP was not required for the growth of B103.

\section{B103 cells transfected with APP expression plasmids extend more neurites}

After transfection of B 103 cells with an APP expression plasmid construct, we selected several clonal B103 lines with high levels of APP expression (Schubert and Behl, 1993): B103/695 clones produced APP-695, whereas B103/Neo clones were controls transfected with the expression vector only. B103/695 and B103/ Neo did not differ in growth rate or in morphology when grown in serum-containing medium. To induce morphological differentiation of B103 cells (Schubert et al., 1974), clones of transfected cells were cultured in N2 serum-free defined medium (Bottenstein and Sato, 1979), and their morphology was compared. Figure 2 shows the morphology of a clone of B103/Neo and a clone of B103/695 cultured for $30 \mathrm{hr}$ at equal density ( 5 $\times 10^{3} \mathrm{cells} / \mathrm{cm}^{2}$ ) in $\mathrm{N} 2$ medium on tissue culture plastic. While $\mathrm{B} 103 /$ Neo cells had begun to grow neurites, the B103/695 culture already had long neurites. Although we cultured cells for $30 \mathrm{hr}$ in this experiment, we employed $20 \mathrm{hr}$ culture conditions for later experiments with essentially the same results. Quantification of independent cultures at $20 \mathrm{hr}$ after plating demonstrated that the average neurite number per cell (Fig. 2C) and the neurite length (Fig. $2 D$ ) were significantly increased in the B103/695 cells as compared to B103/Neo cells. Furthermore, when CM from B103/695 cultures was placed on B103 cells, it induced neurite extension; CM from B103/Neo cultures did not (Fig. 2C,D). CM from other APP-695-overproducing B103 clones obtained from the same transfection also enhanced neu-

\begin{tabular}{|c|c|c|c|}
\hline Peptide & Sequence & $\mathrm{IC}_{50}(\mathrm{nM})$ & \\
\hline KB75 & APP 20-591 & $11.7 \pm 2.3$ & \\
\hline KB75o & APP 20-591 without $296-335$ & & No inhibition at $1 \mu \mathrm{M}$ \\
\hline R-17 & $M V Q S M R E R H K A E L R E K A$ & & No inhibition at $1 \mu \mathrm{M}$ \\
\hline 17-mer & AKERLEAKHRERMSQVM (APP 319-335) & $12.5 \pm 4.4$ & \\
\hline 8-mer & AKERLEAK & & No inhibition at $1 \mu \mathrm{M}$ \\
\hline 11-mer & AKHRERMSQVM & $35.9 \pm 16.5$ & \\
\hline N5 & AKHRE & & $48 \pm 2 \%$ inhibition at $1 \mathrm{~mm}$ \\
\hline N4 & KHRE & & $32 \pm 3 \%$ inhibition at $1 \mathrm{~mm}$ \\
\hline M6 & HRERMS & $765 \pm 167$ & \\
\hline M5 & RERMS & $842 \pm 111$ & \\
\hline $\mathrm{C} 7$ & ERMSQVM & & $70 \pm 5 \%$ inhibition at $1 \mathrm{~mm}$ \\
\hline $\mathrm{C} 6$ & RMSQVM & & $61 \pm 7 \%$ inhibition at $1 \mathrm{~mm}$ \\
\hline
\end{tabular}

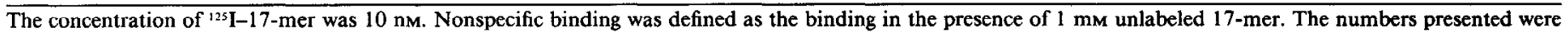
calculated from the data shown in Figure $5 D-F$ (means \pm SEM of at least three determinations, each done in triplicate). 

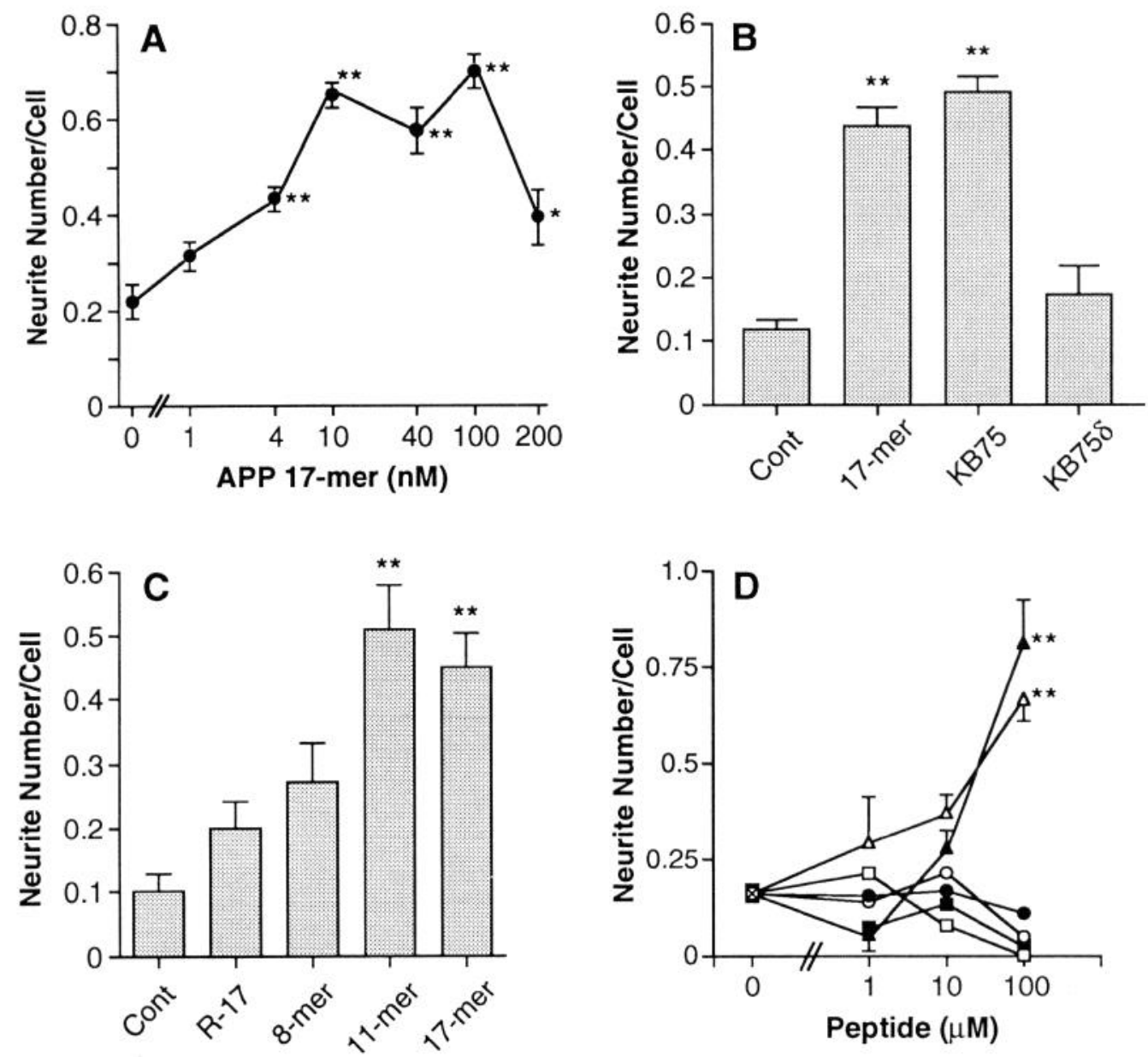

Figure 4. Bacteria-produced sAPP and its active domain peptides induce neurite extension from B103 cells. Quantification of neurite number per cell after $20 \mathrm{hr}$ treatment of various APP peptides. Data were analyzed by ANOVA with post hoc Dunnett test. APP 17-mer induced neurite extension in a dose-dependent fashion $(A)$. Above $4 \mathrm{~nm}$ the effect of 17 -mer was significant $\left({ }^{*}, p<0.05 ;{ }^{* *}, p<0.01\right.$; compared to nonpeptide group). A reduced effect was observed at above $200 \mathrm{nM}$. Compared to the control, KB75 (40 nM) and APP 17-mer (40 nM), but not KB75 $\delta$ (40 nM), induced more neurites per cell $(B)(* *, p<0.01)$. Data from experiments using $40 \mathrm{~nm}$ of the APP peptides (Table 1) are presented in $C$. Compared to the control, APP 11-mer and APP 17-mer induced more neurite extension per B103 cell (**, $p<0.01)$, but R-17 and APP 8-mer did not have a significant effect on neurite extension. In $D$, effects of small peptides within APP 11-mer (Table 1) were examined. O, N4; $\bullet$, N5; $\triangle$, M5; $\mathbf{\Delta}, \mathrm{M} 6 ; \square, \mathrm{C6} ; \mathbf{\square}, \mathrm{C} 7$. Compared to control $(\otimes)$, M5 and M6 at $100 \mu \mathrm{M}$ had significant $(p<0.01)$ neurite induction effect. For the sake of clarity, some error bars are not shown.

rite extension. These data suggested that secreted proteins, possibly sAPP-695, promoted the neurite extension.

SAPP produced in $\mathrm{E}$. coli promotes neurite extension by $B 103$ cells

To confirm the neurite extension activity of sAPP, however, a pure sAPP preparation was required. Using a prokaryotic expression system, we produced an APP polypeptide, KB75 (Val20 to Ile-591), corresponding to SAPP-695, which does not contain the $\mathrm{A} \beta$ domain (Roch et al., 1992). At concentrations from 10 to $100 \mathrm{nM}$, purified KB75 induced neurite extension in B103 culture (Fig. 3, open circles) to the level seen in B103/695 culture. No significant change of cell number or ${ }^{3} \mathrm{H}$-thymidine incorporation was observed after KB75 treatment of B103 cells (data not shown). Above $200 \mathrm{nM}$, our preparation of KB75 was toxic to $\mathrm{B} 103$ cells. This range of effective concentrations for neurite extension agrees with that reported by Araki et al. (1991) using sAPP purified from CM of APP-overproducing cells. KB75 had no additional effect on the morphology of B103/695.
The APP domain containing the RERMS sequence represents the active site for promotion of neurite extension by B103 cells As shown in Figure $4 A$, a synthetic peptide corresponding to Ala-319 to Met-335 of APP-695 (Kang et al., 1987) (APP 17mer; see Table 1 for amino acid sequence) was also active in stimulating neurite extension of B103 cells in a dose-dependent manner. A deletion mutant of KB75 (named KB75 $)$ ) that does not contain the active 17-mer domain (Ninomiya et al., 1993) did not show a significant effect on neurite extension (Fig. $4 B$ ). The 17-mer peptide neither increased cell number nor enhanced short-term cell-substratum adhesion (data not shown), in contrast to sAPP purified from CM (Schubert et al., 1989). To show the sequence specificity, we tested the 17 -mer peptide, an 8-mer peptide at the N-terminal of the 17-mer, an 11-mer peptide at the C-terminal of the 17-mer, and a control peptide with sequence reversed from that of APP 17-mer (named R-17, Table 1). As shown in Figure $4 C$, at 40 nM, APP 17-mer and 11-mer peptides significantly promoted neurite extension when com- 

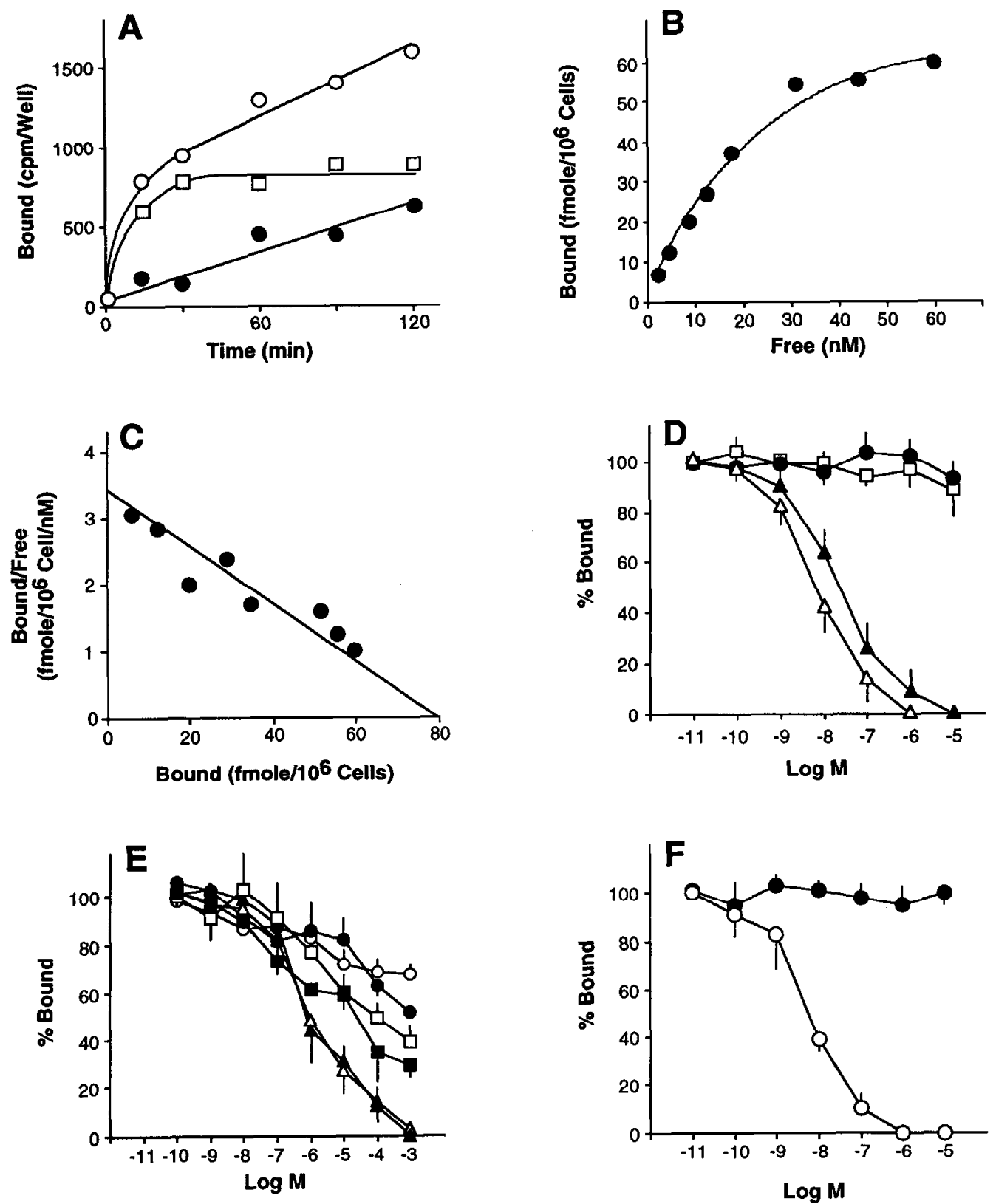

Figure 5. APP 17-mer binds specifically and in a saturable manner to a B103 cell-surface molecule. The specific binding was obtained by subtracting nonspecific binding (binding measured in the presence of $1 \mathrm{~mm}$ unlabeled 17-mer) from the total binding. $A$, Time course of ${ }^{125} \mathrm{I}-17$-mer (15 nM) binding to the B103 cell layer. The data shown are the means of the triplicate determinations in a single experiment. $O$, total binding; $\square$, specific binding; , nonspecific binding. $B$, Saturation curve of ${ }^{125}$ I-17-mer binding to B103 cell layer. The reaction time was $1 \mathrm{hr}$. The data shown are the specific binding (means of the triplicate determinations in a single experiment). $C$, Scatchard plot of the data in $B$. $D$, Inhibition of ${ }^{125}[-17-$ mer binding to the B 103 cell layer by unlabeled 17 -mer or by its fragments. The binding assay was performed with $10 \mathrm{nM}{ }^{125} \mathrm{I}-17-\mathrm{mer}$ in the presence of various concentrations of unlabeled 17-mer $(\triangle)$, R-17 (O), 11-mer $(\Delta)$, or 8-mer $(\square)$. Data presented are specific binding (means \pm SEM of three determinations, each done in triplicate). $E$, Same experiment as in $D$, except subfragments of 11-mer were used to compete with ${ }^{125}$ I-17-mer binding. $0, \mathrm{~N} 4 ; \mathbf{O}, \mathrm{N} 5 ; \triangle, \mathrm{M} 5 ; \Delta, \mathrm{M} 6 ; \square, \mathrm{C} 6 ; \mathbf{D}, \mathrm{C} 7$. The sequences of these APP peptides and the binding parameters are given in Table $1 . F$, Same experiment as in $D$, except $\mathrm{KB} 75(\mathrm{O})$ or $\mathrm{KB} 75 \delta(0)$ was used to compete with ${ }^{125} \mathrm{I}-17$-mer binding.

pared to a control culture, but 8 -mer and R-17 did not. To identify the minimum sequence requirement for the neurite extension activity of SAPP, we tested shorter peptides within the 11-mer sequence. We found that a pentamer peptide, RERMS (M5), stimulated neurite extension, although only at a high concentration (Fig. 4D). The N-terminal or C-terminal portion of the 11-mer peptide did not have any neurite-promoting activity (N5, N4, C7, and C6; see Table 1, Fig. 4D).

\section{APP peptide binds to detergent-extractable site on $B 103$ cells}

Since the neurite extension activity of APP requires specific sequence, it may be mediated through cell-surface molecules interacting with that sequence. To test this possibility, binding assays were carried out using 17-mer peptide labeled with Bolton-Hunter reagent (called ${ }^{125} \mathbf{I}-17$-mer) on a B103 cell monolayer. The detergent-extractable binding of ${ }^{125} \mathbf{I}-17$-mer to the 


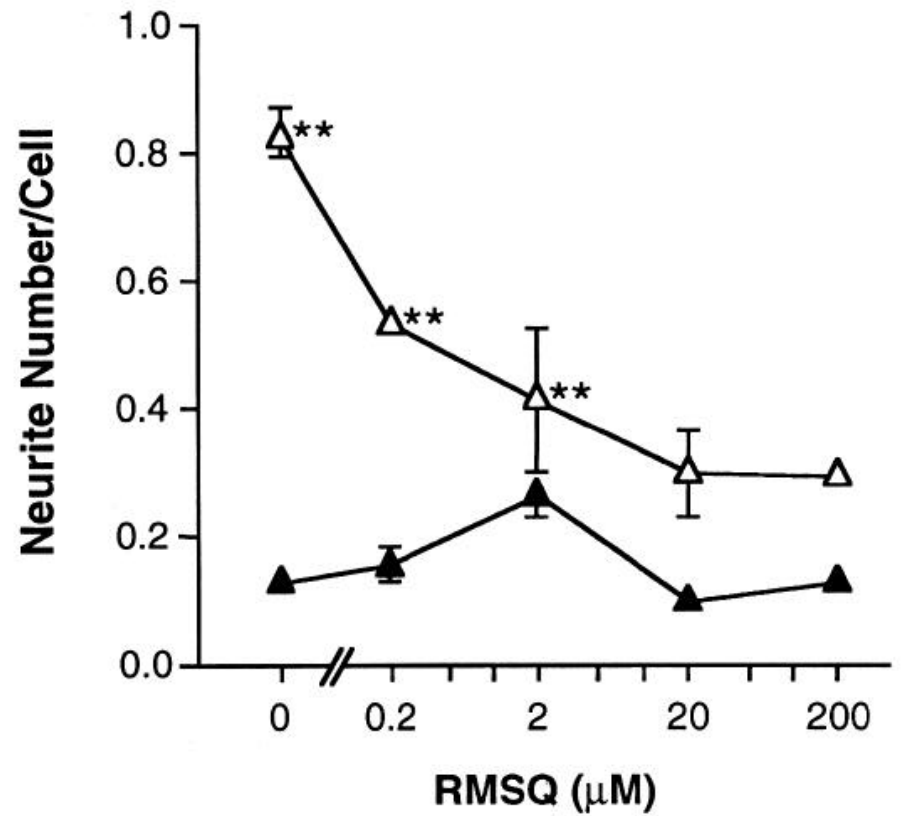

Figure 6. The RMSQ sequence antagonizes the effect of KB75. Data were pooled from three separate experiments and analyzed by ANOVA followed by the post hoc Dunnett test. B103 cells were cultured in the presence of the indicated concentration of RMSQ peptide with $(\Delta)$ or without (A) $40 \mathrm{~nm} \mathrm{KB75}$ for $20 \mathrm{hr}$. The ability of $40 \mathrm{~nm} \mathrm{KB75}$ to stimulate neurite extension was blocked in the presence of RMSQ at concentrations above $20 \mu \mathrm{M}$ (**, $p<0.01$ compared with no treatment). Note that RMSQ by itself at a wide range of concentrations did not have any effect.

B103 cell layer was time dependent (Fig. $5 A$ ) and saturable (Fig. $5 B$ ) with a $K_{D}$ value of $20 \pm 5 \mathrm{nM}$ and a $B_{\max }$ value of $80 \pm 8$ fmol/ $10^{6}$ cells, as determined by Scatchard analysis (Fig. $5 C$ ) (Scatchard et al., 1949). This number corresponds to approximately $5 \times 10^{4}$ binding sites per cell. The binding was sequence specific because 17-mer, but not R-17, could displace the binding, and the C-terminal 11-mer of the 17-mer displaced the binding, whereas N-terminal 8-mer did not (Fig. 5D). The inhibition study using various fragments of the 11-mer peptide (Fig. $5 E$ ) suggested that the five-amino-acid sequence (RERMS) in the middle portion of the 11-mer peptide is important for the binding activity (Table 1 ). The binding was displaced by KB75 but not by KB75 $\delta$ (Fig. $5 F$ ). Therefore, a domain containing the RERMS sequence in the secreted form of APP-695 is likely to be recognized by cell-surface molecules.

\section{The peptide RMSQ antagonizes APP effect to promote neurite extension}

As RERMS seems to be a critical sequence of sAPP- 695 for both the cell-surface binding and biological activity, peptides with sequences that partially overlap RERMS and lack biological activity might compete for the binding site and antagonize the effect of active APP fragments. To test this possibility, we examined the RMSQ (APP 330-333) peptide that has been shown to block the APP activity in fibroblast growth assay (Ninomiya et al., 1993). RMSQ at concentrations above $20 \mu \mathrm{M}$ significantly blocked neurite extension from B103 cells treated with $40 \mathrm{~nm}$ of KB75 (Fig. 6) or 17-mer (data not shown). The RMSQ peptide at those concentrations had no obvious effect on $\mathrm{B} 103$ cells by itself and was not cytotoxic. The blocking effect was sequence specific because APP 8-mer, which did not inhibit

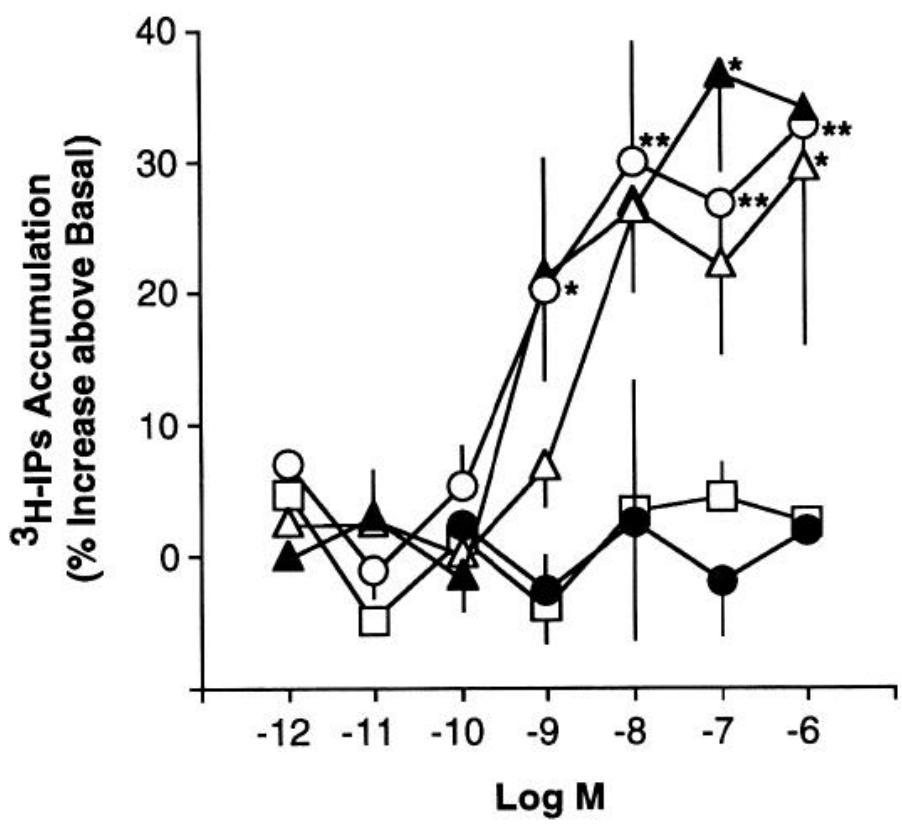

Figure 7. PI turnover in B103 cells stimulated by APP fragments. The effect of APP peptides on the production of ${ }^{3} \mathrm{H}$-inositol phosphates was expressed as percentage increase above basal (untreated). Each point represents the mean \pm SEM of at least three determinations. APP 11mer $(\Delta), 17-\operatorname{mer}(\Delta)$, and KB75 $(0)$ stimulated significant PI turnover, whereas 8-mer $(\bullet)$ and R-17 ( $\square$ ) had no significant effect. ${ }^{*}, p<0.05$; **, $p<0.01$; compared with no peptide group.

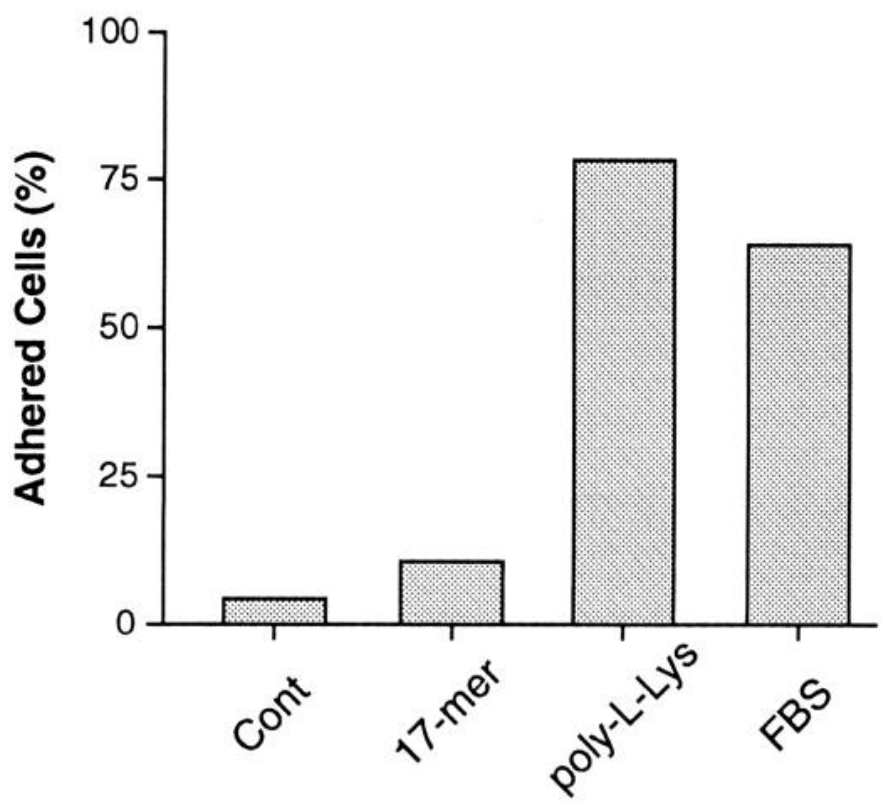

Figure 8. APP 17-mer does not stimulate cell adhesions. The data presented are the percentage of input cells (radioactivity) that adhered at $30 \mathrm{~min}$ incubation. The following reagents were precoated to the dishes: $100 \mathrm{pmol}$ of APP 17-mer, $0.25 \mu \mathrm{g}$ of poly-L-lysine (MW 30,00070,000 ), and $10 \%$ fetal bovine serum (FBS) in $0.5 \mathrm{ml}$ of DME. Note that the amounts of 17 -mer used to coat dishes were equivalent to 200 $\mathrm{nM}$ in $0.5 \mathrm{ml}$ of solution. The lower concentrations of $17-$ mer coating did not have any effects on adhesion. The experiment was repeated twice with essentially identical results. 
APP 17-mer binding, did not block the effect of APP 17-mer or KB75, even at a 1000-fold higher concentration (data not shown). This inhibition effect was reversible, since a higher concentration (100 nM) of KB75 overcame the antagonism of $20 \mu \mathrm{M}$ RMSQ (Fig. 3, solid circles). These data suggest that RMSQ blocks APP activity to promote neurite extension through competition for the same binding site. They also suggest that the RERMS domain of APP is the active site required for the neurite extension activity of this molecule, supporting the conclusion obtained with KB75 $\delta$.

\section{APP binding induces phosphoinositide turnover}

Phosphoinositide (PI) turnover represents the transduction mechanism of some neurotransmitters and neurotrophic factors acting through surface receptors (Berridge and Irvine, 1989). Because active APP peptides bind to neuronal surface molecules, we tested whether they also induce PI turnover. As shown in Figure 7, at concentrations comparable to those effective for neurite extension and binding activity, KB75, 17-mer, and 11mer stimulated the accumulation of inositol polyphosphates. Inactive peptides 8-mer and R-17 did not stimulate the accumulation of inositol polyphosphates, indicating the sequence specificity of the effect.

\section{APP peptide does not increase cell adhesion to substratum}

The rate of neurite outgrowth is partly determined by how tightly the cells adhere to the substratum. To determine whether the neurite induction by APP 17-mer is through the enhancement of adhesiveness, we measured the initial adherence rate of B103 cells plated into dishes coated with APP 17-mer. Figure 8 demonstrates that at concentrations equivalent to our neurite extension experiments, 17-mer that adhered to the dish surface did not enhance the initial adherence rate of B103 cells, whereas under similar conditions poly-L-lysine and FBS did enhance the adhesion. On the other hand, we demonstrated previously that purified APP at the femtomolc rangc enhanced the rapid adherence of PC12 cells to dishes (Schubert et al., 1989). Thus, APP 17-mer does not represent a domain responsible for the adhesion-promoting effect of APP.

\section{Discussion}

We demonstrated that the secreted form of APP-695 promotes neurite extension of $\mathrm{B} 103$ cells. The neuritotropic activity of APP resides in the middle domain of APP containing RERMS, and is independent of the KPI (Robakis et al., 1990) or A $\beta$ (Whitson et al., 1989, 1990; Yankner et al., 1990) domains that are reported to be neurotrophic. The neurite induction, cellsurface binding, and induction of inositol polyphosphate accumulation all require the same amino acid sequence and a similar concentration range. Although RERMS seems to be the most important sequence in APP for its neuritotropic activity, the surrounding amino acids also contribute to binding and biological activity, since RERMS's neuritotropic activity is orders of magnitude less than that of KB75 and the 17-mer peptide. Nevertheless, the requirement of the specific sequence for neurite-extending activity suggests the presence of a potential APP receptor. This is further suggested by the identification of a competitive peptide antagonist, RMSQ. The presence of approximately 50,000 APP binding sites per cell that are extractable by nonionic detergent also argues for the presence of an APP receptor on the cell surface.

There are two plausible mechanisms for APP to promote neurite extension, one through membrane receptor activation and the other through a mechanism that increases cell adhesiveness to the substratum, although these two mechanisms are not mutually exclusive. Our binding study demonstrated that the APP recombinant proteins or peptides bound specifically to detergent-extractable cell-surface molecules, but did not bind specifically to the substratum. The specific binding was dependent on the presence of cells: the culture dish had only nonsaturable and nonreplaceable binding. Furthermore, we observed comparable APP binding $\left(\sim 50,000\right.$ sites/cell, $\left.\sim 20 \mathrm{nM} K_{D}\right)$ in cell suspension assays or in assays with purified membrane fractions (data not shown). Although APP 17-mer peptide adsorbed to the culture dish did not promote cell adhesion to the substratum (Fig. 8), APP preadsorbed to the culture dish did promote cell adhesion to the substratum (Schubert et al., 1989). This APP effect on cell adhesion may be related to its activity to bind heparan sulfate proteoglycan (Narindrasorasak et al., 1991; Small et al., 1992, 1993; Buee et al., 1993; Ninomiya et al., 1994), collagen (Breen, 1992), or laminin (Narindrasorasak et al., 1992; Kibbey et al., 1993). We investigated several conditions to diminish the nonspecific binding of the APP recombinant proteins and peptides to substratum. We found that BSA actually increased the nonspecific APP binding to substratum. This is why we used gelatin in our binding assay to decrease the nonspecific binding. The inclusion of these proteins in the assay medium did not alter the efficacy of the APP 17-mer peptide to promote neurite extension. As the 17-mer APP peptide does not stimulate cell substratum adhesion, it is not likely that the 17-mer peptide promotes neurite outgrowth by increasing cell adhesion. Instead, its activity is probably through cell-surface binding and possibly through a receptor-mediated mechanism. However, despite data that suggest the presence of APP receptors, it is extremely difficult to exclude the possibility that the biological function of the APP recombinant protein and peptides is through substratum binding and not through receptor binding. The final conclusion as to the mechanisms of APP function might be drawn when the putative APP receptor is cloned and the receptor "knock out" experiments are carried out.

Milward et al. (1992) demonstrated that either soluble or membrane-associated APP purified from human brain had a neurite-promoting effect on $\mathrm{PC} 12$ at a concentration of $10^{-10}$ M. The neurite outgrowth effect of APP observed by Milward et al. (1992) may be through modulation of cell adhesion (Schubert et al., 1989), or it may be due to the receptor-mediated mechanism we propose in this report. In their culture system, APP was added to $24 \mathrm{hr}$ subcultures of PC12 in serum-containing medium. Thus it is probable that extracellular matrix (ECM) and endogenous APP had been deposited onto the substratum. The complex interaction of added APP with endogenous APP, ECM components (Klier et al., 1990; Small et al., 1992, 1993), and serum proteins cannot be neglected. In the present B103 culture system, we did not have interference from serum proteins and endogenous APP. We also eliminated the possible interaction with ECM components by adding APP at the time of cell plating. Furthermore, APP 17-mer does not bind heparan sulfate proteoglycan or ECM (Ninomiya et al., 1993). The possible contaminating activity besides that of sAPP in the purified protein samples (Saitoh et al., 1989; Araki et al., 1991; Bhasin et al., 1991; Milward et al., 1992) was also avoided in our experiments by using synthetic peptides. In addition, our active APP peptides do not contain a cell adhesion-promoting sequence attributed to $\mathrm{A} \beta$ (Breen et al., 1991; Ghiso et al., 1992; 
Koo et al., 1993), and they did not promote cell-substratum adhesion (Fig. 8).

Further confirmation of the biological significance of neurite extension activity of APP requires the demonstration of the presence of the active APP fragment and the receptor in the normal neuronal environment and the effect in vivo. The presence of the N-terminal portion of APP in cerebrospinal fluid indicates that it is probably secreted and available in the brain. Additionally, APP is physiologically released from rat hippocampal slices (Nitsch et al., 1993). APP undergoes fast anterograde axonal transport (Koo et al., 1990), and may be secreted into the synaptic cleft. The neurite extension activity of sAPP reported here and by others (Araki et al., 1991; Milward et al., 1992) may be involved in the maintenance of synaptic integrity, as previously suggested (Schubert, 1991; Price et al., 1992).

\section{References}

Anderson JP, Esch FS, Keim PS, Sambamurti K, Lieberburg I, Robakis NK (1991) Exact cleavage site of Alzheimer amyloid precursor in neuronal PC-12 cells. Neurosci Lett 128:126-128.

Arai H, Lee VM, Otvos L Jr, Greenberg BD, Lowery DE, Sharma SK, Schmidt ML, Trojanowski JQ (1990) Defined neurofilament, tau, and $\beta$-amyloid precursor protein epitopes distinguish Alzheimer from non-Alzheimer senile plaques. Proc Natl Acad Sci USA 87:2249 2253.

Araki W, Kitaguchi N, Tokushima Y, Ishii K, Aratake H, Shimohama S, Nakamura S, Kimura J (1991) Trophic effect of $\beta$-amyloid precursor protein on cerebral cortical neurons in culture. Biochem Biophys Res Commun 181:265-271.

Bernard HU, Oltersdorf T, Seedorf K (1987) Expression of the human papillomavirus type $18 \mathrm{E} 7$ gene by a cassette-vector system for the transcription and translation of open reading frames in eukaryotic cells. EMBO J 6:133-138.

Berridge MJ, Irvine RF (1989) Inositol phosphates and cell signalling. Nature 341:197-205.

Bhasin R, Van Nostrand WE, Saitoh T, Donets MA, Barnes EA, Quitschke WW, Goldgaber D (1991) Expression of active secreted forms of human amyloid $\beta$-protein precursor by recombinant baculovirus-infected insect cells. Proc Natl Acad Sci USA 88:10307-10311.

Bottenstein JE, Sato GH (1979) Growth of a rat neuroblastoma cell line in serum-free supplemented medium. Proc Natl Acad Sci USA 76:514-517.

Breen KC (1992) APP-collagen interaction is mediated by a heparin bridge mechanism. Mol Chem Neuropathol 16:109-121.

Breen KC, Bruce M, Anderton BH (1991) Beta amyloid precursor protein mediates neuronal cell-cell and cell-surface adhesion. J Neurosci Res 28:90-100.

Buee L, Ding W, Delacourte A, Fillit H (1993) Binding of secreted human neuroblastoma proteoglycans to the Alzheimer's amyloid A4 peptide. Brain Res 601:154-163.

Chomczynski P, Sacchi N (1987) Single-step method of RNA isolation by acid guanidinium thiocyanate-phenol-chloroform extraction. Anal Biochem 162:156-159.

Cole GM, Masliah E, Shelton ER, Chan HW, Terry RD, Saitoh T (1991) Accumulation of amyloid precursor fragment in Alzheimer's plaques. Neurobiol Aging 12:85-91.

Cras P, Kawai M, Lowery D, Gonzalez-DeWhitt P, Greenberg B, Perry G (1991) Senile plaque neurites in Alzheimer disease accumulate amyloid precursor protein. Proc Natl Acad Sci USA 88:7552-7556.

Cummings BJ, Su JH, Geddes JW, Van Nostrand WE, Wagner SL, Cunningham DD, Cotman CW (1992) Aggregation of the amyloid precursor protein within degenerating neurons and dystrophic neurites in Alzheimer's disease. Neuroscience 48:763-777.

Esch FS, Deim PS, Beattie E, Blacher RW, Culwell AR, Oltersdorf T, McClure D, Ward PJ (1990) Cleavage of amyloid $\beta$ peptide during constitutive processing of its precursor. Science 248:1122-1124.

Ghiso J, Tagliavini F, Timmers WF, Frangione B (1989) Alzheimer's disease amyloid precursor protein is present in senile plaques and cerebrospinal fluid: immunohistochemical and biochemical characterization. Biochem Biophys Res Commun 163:430-437.

Ghiso J, Rostagno A, Gardella JE, Liem L, Gorevic PD, Frangione B
(1992) A 109-amino-acid C-terminal fragment of Alzheimer's-disease amyloid precursor protein contains a sequence, -RHDS-, that promotes cell adhesion. Biochem J 288:1053-1060.

Glenner GG, Wong CW (1984) Alzheimer's disease and Down's syndrome: sharing of a unique cerebrovascular amyloid fibril protein. Biochem Biophys Res Commun 122:1131-1135.

Goldgaber D, Lerman MI, McBride OW, Saffiotti U, Gajdusek DC (1987) Characterization and chromosomal localization of a cDNA encoding brain amyloid of Alzheimer's disease. Science 235:877-880.

Joachim C, Games D, Morris J, Ward P, Frenkel D, Selkoe D (1991) Antibodies to non-beta regions of the beta-amyloid precursor protein detect a subset of senile plaques. Am J Pathol 138:373-384.

Kang J, Lemaire H-G, Unterbeck A, Salbaum MJ, Masters CL, Grzeschik K-H, Multhaup G, Beyreuther K, Müller-Hill B (1987) The precursor of Alzheimer's disease amyloid A4 protein resembles a cellsurface receptor. Nature 325:733-736.

Kibbey MC, Jucker M, Weeks BS, Neve RL, Van Nostrand WE, Kleinman HK (1993) $\beta$-Amyloid precursor protein binds to the neuritepromoting IKVAV site of laminin. Proc Natl Acad Sci USA 90: 10150-10153.

Kitaguchi N, Takahashi Y, Tokushima Y, Shiojiri S, Ito H (1988) Novel precursor of Alzheimer's disease amyloid protein shows protease inhibitory activity. Nature 331:530-532.

Klicr FG, Colc G, Stallcup W, Schubert D (1990) Amyloid $\beta$-protein precursor is associated with extracellular matrix. Brain Res 515:336342.

Koo EH, Sisodia SS, Archer DA, Martin LJ, Weidemann A, Beyreuther K, Masters CL, Fisher P, Price DL (1990) Precursor of amyloid protein in Alzheimer's disease undergoes fast anterograde axonal transport. Proc Natl Acad Sci USA 87:1561-1565.

Koo EH, Park L, Selkoe DJ (1993) Amyloid $\beta$-protein as a substrate interacts with extracellular matrix to promote neurite outgrowth. Proc Natl Acad Sci USA 90:4748-4752.

Masliah E, Mallory M, Hansen L, Alford M, DeTeresa R, Terry RD, Baudier J, Saitoh T (1992a) Localization of amyloid precursor protein in GAP-43 immunoreactive aberrant sprouting neurites in Alzheimer's disease. Brain Res 574:312-316.

Masliah E, Mallory M, Gc N, Saitoh T (1992b) Protein kinases and growth associated proteins in plaque formation in Alzheimer's disease. Rev Neurosci 3:99-107.

Masliah E, Mallory M, Ge N, Saitoh T (1992c) Amyloid precursor protein is localized in growing neurites of neonatal rat brain. Brain Res 593:323-328.

Masters CL, Multhaup G, Simms G, Pottgiesser J, Martins RN, Beyreuther K (1985) Neuronal origin of a cerebral amyloid: neurofibrillary tangles of Alzheimer's disease contain the same protein as the amyloid of plaque cores and blood vessels. EMBO J 4:2757-2763.

Mattson MP, Cheng B, Culwell AR, Esch FS, Lieberburg I, Rydel RE (1993) Evidence for excitoprotective and intraneuronal calcium-rcgulating roles for secreted forms of the $\beta$-amyloid precursor protein. Neuron 10:243-254.

Milward EA, Papadopoulos R, Fuller SJ, Moir RD, Small D, Beyreuther K, Masters CL (1992) The amyloid protein precursor of Alzheimer's disease is a mediator of the effects of nerve growth factor on neurite outgrowth. Neuron 9:129-137.

Narindrasorasak S, Lowery D, Gonzalez-DeWhitt P, Poorman RA, Greenberg B, Kisilevsky R (1991) High affinity interactions between the Alzheimer's beta-amyloid precursor proteins and the basement membrane form of heparan sulfate proteoglycan. J Biol Chem 266: 12878-12883.

Narindrasorasak S, Lowery DE, Altman RA, Gonzalez-DeWhitt P, Greenberg BD, Kisilevsky R (1992) Characterization of high affinity binding between laminin and Alzheimer's disease amyloid precursor proteins. Lab Invest 67:643-652.

Ninomiya H, Roch J-M, Sundsmo MP, Otero DAC, Saitoh T (1993) Amino acid sequence RERMS represents the active domain of amyloid $\beta /$ A4 protein precursor that promotes fibroblast growth. J Cell Biol 121:879-886.

Ninomiya H, Roch J-M, Jin L-W, Saitoh T (1994) Secreted form of APP binds to two distinct APP binding sites on B103 rat neuronal cells through two different domains, but only one site is involved in trophic activity. J Neurochem, in press.

Nishimoto I, Okamoto T, Matsuura Y, Takahashi S, Okamoto T, Murayama $Y$, Ogata $E$ (1993) Alzheimer amyloid protein precursor complexes with brain GTP-binding protein $G(0)$. Nature 362:75-79. 
Nitsch RM, Farber SA, Growdon JH, Wurtman RJ (1993) Release of amyloid $\beta$-protein precursor derivatives by elcctrical depolarization of rat hippocampal slices. Proc Natl Acad Sci USA 90:5191-5193.

Palmert MR, Podlisny MB, Witker DS, Oltersdorf T, Younkin LH, Selkoe DJ, Younkin SG (1989a) The $\beta$-amyloid protein precursor of Alzheimer's disease has soluble derivatives found in human brain and cerebrospinal fluid. Proc Natl Acad Sci USA 86:6338-6342.

Palmert MR, Siedlak SL, Podlisny MB, Greenberg B, Shelton ER, Chan HW, Usiak M, Selkoe DJ, Perry G, Younkin SG (1989b) Soluble derivatives of the $\beta$ amyloid protein precursor of Alzheimer's disease are labeled by antisera to the $\beta$ amyloid protein. Biochem Biophys Res Commun 165:182-188.

Podlisny MB, Mammen AL, Schlossmacher MG, Palmert MR, Younkin SG, Selkoe DJ (1990) Detection of soluble forms of the $\beta$-amyloid precursor protein in human plasma. Biochem Biophys Res Commun 167:1094-1101.

Ponte P, Gonzalez-DeWhitt P, Schilling J, Miller J, Hsu D, Greenberg B, Davis K, Wallace W, Lieberburg I, Fuller F, Cordell B (1988) A new A4 amyloid mRNA contains a domain homologous to serine proteinase inhibitors. Nature 331:525-527.

Price DL, Martin LJ, Clatterbuck RE, Koliatsos VE, Sisodia SS, Walker LC, Cork LC (1992) Neuronal degeneration in human diseases and animal models. J Neurobiol 23:1277-1294.

Prior R, Monning U, Schreiter-Gasser U, Weidemann A, Blennow K, Gottfries CG, Masters CL, Beyreuther K (1991) Quantitative changes in the amyloid beta A4 precursor protein in Alzheimer cerebrospinal fluid. Neurosci Lett 124:69-73.

Refolo LM, Salton SR, Anderson JP, Mehta P, Robakis NK (1989) Nerve and epidermal growth factors induce the release of the Alzheimer amyloid precursor from PC 12 cell cultures. Biochem Biophys Res Commun 164:664-670.

Robakis NK, Ramakrishna N, Wolfe G, Winsiewski HM (1987) Molecular cloning and characterization of a cDNA encoding the cerebrovascular and the neuritic plaque amyloid peptides. Proc Natl Acad Sci USA 84:4190-4194.

Robakis NK, Altstiel LD, Refolo LM, Anderson JP (1990) Function and metabolism of the protease inhibitor-containing Alzheimer amyloid precursors. In: Molecular biology of Alzheimer's disease (Miyatake T, Selkoe DJ, Ihara Y, eds), pp 179-188. Amsterdam: Elsevier.

Roch J-M, Shapiro IP, Sundsmo M, Otero DAC, Refolo LM, Robakis NK, Saitoh T (1992) Bacterial expression, purification and functional mapping of the amyloid $\beta / \mathrm{A} 4$ protein precursor. J Biol Chem 267:2214-2221.

Saitoh T, Sundsmo M, Roch J-M, Kimura N, Cole G, Schubert D, Oltersdorf T, Schenk DB (1989) Secreted form of amyloid $\beta$-protein precursor is involved in the growth regulation of fibroblasts. Cell 58: 615-622.

Scatchard G (1949) The attractions of proteins for small molecules and ions. Ann NY Acad Sci 51:660-672.

Schubert D (1991) The possible role of adhesion in synaptic modification. Trends Neurosci 14:127-130.

Schubert D, Behl C (1993) The expression of amyloid beta protein precursor by a nerve cell line alters its interaction with extracellular matrix. Brain Res 629:275-282.

Schubert D, Heinemann S, Carlisle W, Tarikas H, Kimes B, Patrick J, Steinbach JH, Culp W, Brandt BL (1974) Clonal cell lines from the rat central nervous system. Nature 249:224-227.

Schubert D, Schrocder R, LaCorbicrc M, Saitoh T, Cole G (1988) Amyloid $\beta$-protein precursor is possibly a heparan sulfate proteoglycan core protein. Science 241:223-241.
Schubert D, Jin L-W, Saitoh T, Cole G (1989) The regulation of amyloid $\beta$ protein precursor secretion and its modulatory role in cell adhesion. Neuron 3:689-694.

Selkoe DJ, Abraham CR, Podlisny MB, Duffy LK (1986) Isolation of low-molecular-weight protein from amyloid plaque fibers in Alzheimer's disease. J Neurochem 46:1820-1834.

Selkoe D, Podlisny M, Joachim C, Vickers E, Lee G, Fritz L, Oltersdorf $T$ (1988) $\beta$-Amyloid precursor protein occurs as 110 to 135 kilodalton membrane-associated proteins in neural and non-neuronal tissues. Proc Natl Acad Sci USA 85:7341-7345.

Seubert P, Oltersdorf T, Lee MG, Barbour R, Blomquist C, Davis DL, Bryant K, Fritz LC, Galasko D, Thal LJ, Lieberburg I, Schenk DB (1993) Secretion of $\beta$-amyloid precursor protein cleaved at the amino terminus of the $\beta$-amyloid peptide. Nature 361:260-263.

Shoji M, Hirai S, Yamaguchi H, Harigaya Y, Ishiguro K, Matsubara E (1991) Alpha 1-antichymotrypsin is present in diffuse senile plaques. A comparative study of $\beta$-protein and $\alpha 1$-antichymotrypsin immunostaining in the Alzheimer brain. Am J Pathol 138:247-257.

Sisodia SS, Koo EH, Beyreuther K, Unterbeck AJ, Price DL (1990) Evidence that $\beta$-amyloid protein in Alzheimer's disease is not derived by normal processing. Science 248:492-495.

Small DH, Nurcombe V, Moir R, Michaelson S, Monard D, Beyreuther $\mathrm{K}$, Masters CL (1992) Association and release of the amyloid protein precursor of Alzheimer's disease from chick brain extracellular matrix. J Neurosci 12:4143-4150.

Small DH, Nurcombe V, Clarris H, Beyreuther K, Masters CL (1993) The role of extracellular matrix in the processing of the amyloid protein precursor of Alzheimer's disease. Ann NY Acad Sci 695:169 174.

Tanzi RE, Gusella JF, Watkins PC, Bruns GA, St George-Hyslop P, Van Keuren ML, Patterson D, Pagan S, Kurnit DM, Neve RL (1987) Amyloid $\beta$-protein gene: cDNA, mRNA distribution, and genetic linkage near the Alzheimer locus. Science 235:880-884.

Tanzi RE, McClatchey AI, Lamperti ED, Villa-Komaroff L, Gusella JF, Neve RL (1988) Protease inhibitor domain encoded by an amyloid protein precursor mRNA associated with Alzheimer's disease. Nature 331:528-530.

Van Nostrand WE, Wagner SL, Shankle WR, Farrow IS, Dick M, Rozemuller JM, Kuiper MA, Wolters EC, Zimmerman J, Cotman CW, Cunningham DD (1992) Decreased levels of soluble amyloid $\beta$-protein precursor in cerebrospinal fluid of live Alzheimer disease patients. Proc Natl Acad Sci USA 89:2551-2555.

Wang R, Meschia JF, Cotter RJ, Sisodia SS (1991) Secretion of the $\beta / \mathrm{A} 4$ amyloid precursor protein. Identification of a cleavage site in cultured mammalian cells. J Biol Chem 266:16960-16964.

Weidemann A, Konig G, Bunke D, Fischer P, Salbaum JM, Masters CL, Beyreuther K (1989) Identification, biogenesis, and localization of precursors of Alzheimer's disease A4 amyloid protein. Cell 57: 115-126.

Whitson JS, Selkoe DJ, Cotman W (1989) Amyloid beta protein enhances the survival of hippocampal neurons in vitro. Science 243: 1488-1490.

Whitson JS, Glabe CG, Shintani E, Abcar A, Cotman CW (1990) $\beta$ Amyloid protein promotes neuritic branching in hippocampal cultures. Neurosci Lett 110:319-324.

Yankner BA, Duffy LK, Kirschner DA (1990) Neurotrophic and neurotoxic effects of amyloid $\beta$ protein: reversal by tachykinin neuropeptides. Science 250:279-282. 